\title{
The Application and Enlightenment of Micro-course in the Teaching of ideological and political Theory in Colleges and Universities
}

\author{
Junya Zhao \\ Yellow river Conservancy Technical Institute, Yellow River Water Culture Research Center, Kaifeng, China, China
}

\begin{abstract}
With the development of Internet science and technology and the widespread popularity of smart phones, the micro-era, represented by Weibo and WeChat, is coming, and the teaching mode of ideological and political theory course in colleges and universities is facing new challenges and opportunities. How to make good use of "micro-class" has become the problem of changing the traditional teaching mode, arousing students' enthusiasm for learning, enhancing the attraction of ideological and political theory course in colleges and universities, and doing a good job in ideological and political education in colleges and universities. Through the analysis of the definition, characteristics and functions of the micro-course, this paper explores the application process of the micro-course of ideological and political theory, in the hope that the teacher of the course of ideological and political theory can better apply the micro-lesson in the teaching.
\end{abstract}

Keywords-micro course; ideological and political theory course; application; enlightenment

\section{INTRODUCTION}

Ideological work is an extremely important work of the Party and the state. As the forefront of ideological work, colleges and universities shoulder the important task of studying and propagating Marxism, cultivating and promoting the socialist core values, and providing personnel and intellectual support for the realization of the great rejuvenation of the Chinese nation. Colleges and universities are persistently promoting the informationization of education and striving to expand the coverage of high-quality educational resources by means of informationization. In order to reform the teaching mode, the microcourse should be used to change the traditional teaching mode, arouse the enthusiasm of the college students to study the ideological and political theory course, and enhance the attraction and appeal of the ideological and political theory course in colleges and universities.

\section{The Influence OF Micro-COURSE ON IDEOLOGICAL AND POLITICAL THEORY COURSE IN COLLEGES AND UNIVERSITIES}

The word "micro-lesson" comes from abroad, and in a broad sense, it can be called "micro-lecture", "micro-course", "micro-course teaching" and so on. The promotion and application of the word "micro-lesson" in China began with $\mathrm{Hu}$ Tiesheng of Foshan City, Guangdong Province. He believed that "Micro-lesson is based on the core carrier of teaching micro-video, and is based on the knowledge and ability points of a subject (such as knowledge point, skill point, etc. "emotional points, etc.) or a combination of certain teaching elements and links (such as goals, introductions, activities, evaluations, etc.), carefully designed and developed micro-quality learning resources."

Microcourse has the characteristics of clear goal, prominent emphasis, short and sharp, easy to share. It builds the teaching content into thematic unit and small scene in a unique way, and changes the teaching courseware and teaching design of the traditional single resource category in the past. Teaching resources, such as teaching reflection, more effectively highlight the key points and difficulties in the teaching process.

At present, post-00 college students are deeply influenced by new media (Weibo, WeChat, etc.) and network culture. Ideological and political education can not effectively attract the attention of college students only through the traditional teaching method or simple multimedia courseware demonstration. Therefore, the "micro-course", which embodies the modern educational idea and integrates the modern educational technology, is combined with the ideological and political theory course in colleges and universities, and the traditional teaching is combined with the new teaching mode such as micro-lesson. It will not only meet the psychological needs and thinking characteristics of college students after 00 , but also help to improve the teaching effect of ideological and political theory courses in colleges and universities. Specifically. First, the application of micro-class has changed the traditional way of knowledge transfer in ideological and political theory. Although the teaching contents of ideological and political theory courses in colleges and universities are not optional, they can choose to adopt different ways to transfer knowledge to their students. Micro-class shows the teaching content through animation, graphics, audio, video, and so on. It greatly enriches the teaching methods of ideological and political theory and improves the enthusiasm and initiative of college students. Second, the application of micro-class has changed the teaching method of ideological and political theory teachers. The traditional classroom teaching often carries out the whole class or several classes according to the unified progress. When the difficulty is encountered, the teacher often focuses on it. It will be repeated many times. The application of micro-class makes teachers encounter difficulties in the course of teaching, especially before and after class so that students can watch micro-lessons to deepen their knowledge, leaving more time in the classroom to discuss problems, communicate 
problems, and change the way of filling the classroom in the past.

\section{Practical ApPlication of Micro Lesson in IDEOLOGICAL AND POLITICAL THEORY COURSE IN COLLEGES AND UNIVERSITIES}

\section{A. Selection of Content for the Course}

The topic selection is the most important part in the micro course of ideological and political theory. A good selection of topics for the ideological and political theory teaching in colleges and universities can play a multiplier effect, not only can improve students' interest in learning, but also improve the teaching effect of the course content. The selection of topics should follow certain principles: first, to select the theoretical focus in the course of teaching, difficult to make micro-lessons, so that students can repeat the preparation and review many times. Taking Chapter 13 of Mao Zedong's thought and the theoretical system of Socialism with Chinese characteristics (2018 edition) as an example, the main explanation is the diplomacy of great powers with Chinese characteristics. When choosing a theme for microlessons We can choose the knowledge points such as the Community of Human Destiny and the "Belt and Road" initiative as the subject of micro-lesson teaching. On the one hand, these knowledge points are relatively independent and complete, on the other hand, these knowledge points are closely linked to the current situation and policies. It is easy to stimulate the enthusiasm and motivation of students. Second, we should choose the content that follows in the course of teaching as the subject of micro-class. Taking the sixth chapter of the course of ideological and moral cultivation and legal basis (2018 edition) as an example, this paper mainly explains how to abide by the law and abide by the law. In selecting the subject of micro-lesson, we can choose the knowledge points such as "Constitution", "governing the country by law" and "governing the country by virtue" as the subject of micro-lesson teaching. In 2003, these knowledge points can be made into micro-class by students many times to browse to learn. Third, we should choose the content that is relatively repetitive and constantly emphasized in the course of teaching. Take the course "situation and Policy" as an example. Although the contents of each semester of the course are different, there are still similarities in the contents of the "two sessions", "domestic economic situation," three rural issues "and" China's foreign policy "every year. We can select the knowledge points such as "General sense of the two sessions" and "the first document of the Central Committee and the issue of Agriculture, Countryside and Agriculture" and "diplomacy of the Great Power" as the subject of the micro-course, so that students can strengthen the basic common sense content of the situation and policy through pictures and animations.

\section{B. Design of Microcourse Content}

After choosing the theme of the micro-course of ideological and political theory, the teaching design should be carried out according to the teaching content. Take the common sense of the "two sessions" as an example, we can make a comparative design by means of the "two sessions", and through the understanding of the "people's Congress" and the "CPPCC", we can distinguish between the "session" and the "second session," the "representative" and the "member." The difference between "participation in politics" and "exercise of power", "motion" and "proposal". Teaching design is the premise of microcourse recording, and teaching design will directly affect the actual effect of microcourse.

Before recording the teaching design of micro-class, there must be preparation work such as micro-lesson teaching plan, micro-lesson related material, micro-lesson courseware making and so on. The teaching plan of micro-lesson should be focused on and concise in speech. The collection of relevant materials should be based on the teaching design and teaching plan to find relevant pictures, audio and video, micro-lesson courseware should pay attention to the length should not be too long, the background color should not be too complex, to be brief and intrepid.

\section{Recording of Micro Lecture Content}

Microcourses have low barriers to recording, can be a teaching video, can be a recording of PPT, animation, or even a simple word document with narration. Teachers can choose their best use of information technology to show students, teachers can choose to use the camera to mirror, or can choose to record only the sound out of the mirror. Teachers should follow the following principles when choosing recording methods: first, according to the teachers' ability of information technology. At present, video production requires video shooting and post production, often used software such as acoustics, video, Premiere, etc. Animation is often used such as Autodesk 3DS Max or Macromedia Flash software, and even more difficult blue screen matting technology and HD recording and broadcast equipment. As a non-computer major of ideological and political theory teachers, there is no need for gorgeous visual effects, it is important to the best interpretation of the teaching content. The teachers of ideological and political theory can begin with the simple teaching of shooting, shooting courseware or recording screen, and then gradually add professional digital processing techniques such as dubbing, captioning and so on. Second, according to their own hardware production conditions. The main cost of developing microcourses Including video shooting and production, script writing and subtitle production, dubbing and soundtrack, and so on. If the pursuit of shocking visual effects, the cost of production will be greatly increased, will affect the enthusiasm of teachers to create micro-lessons.

\section{Presentation of Microcourse Content}

Micro class can be used flexibly in the teaching of ideological and political theory, and it can be used as preparation, review, introduction, study and so on. Micro lessons are suitable for online learning, autonomous learning and mobile learning, only with a smart mobile terminal, a computer or a smartphone. First of all, microlessons can be transmitted face to face by teachers and students in class, which is the most effective way of transmission, but it is limited by time and place. Secondly, the micro-lessons can be transmitted through the school teaching space platform. The teachers can issue the micro-lessons through their own teaching space, and guide the students to pass through the flat. Download or watch. Third, teachers can also publish the high-quality micro-lessons in the online open video material library, which can not only 
exchange the corresponding points to achieve resource sharing, but also improve the ability of teachers to develop micro-lessons.

The more important part in the application of micro-lesson is the feedback of micro-lesson. The completion of micro-lesson does not mean the end of this task, but the students' evaluation of micro-lesson through teacher-student interaction in classroom teaching. That is to say, to a certain extent, the realization of reverse classroom. Teachers should revise and perfect the micro-lessons in time after the comprehensive opinions, so as to teach each other well.

\section{Application And Enlightenment of Micro-COURSE IN IDEOLOGICAL AND POLITICAL THEORY COURSE IN COLLEGES AND UNIVERSITIES}

\section{A. Teachers of Ideological and Political Theory in Colleges and Universities should Take an Active Part in Learning and Training}

The development of everything depends on each other, challenges and opportunities coexist. Under the background of micro-era, the teachers of ideological and political theory in colleges and universities should not only pay attention to theoretical knowledge and practical ability, but also strengthen the cultivation of information ability of students in colleges and universities, such as obtaining, selecting, processing, creating and so on. Otherwise, it will not meet the needs of the future society. First, the ideological and political theory teachers in colleges and universities should enhance their vision, follow the teaching information technology reform and learn from the application of advanced information technology in micro-course, actively try to combine micro-lesson teaching with classroom teaching, and strengthen their lifelong learning concept. Second, the teachers of ideological and political theory should pay attention to the students' information and moral elements. Foster training and correctly learn through Internet information technology.

\section{B. Teachers of Ideological and Political Theory in Colleges and Universities should Keep Pace with the Times and Grasp Various Skills}

The arrival of the micro-era represents the increasing variety of information technology. Only by skilled use of modern information technology can we lay a good foundation for information teaching ability. Of course, ideological and political theory teachers in colleges and universities should also be aware that technology is only an auxiliary means of teaching. It is important to use these modern information technologies to solve real problems in the course teaching and to achieve the goal of educating people. This is fundamental. Therefore, to realize the deep integration of information technology and ideological and political theory teaching is not only to meet the needs of the current information and modern education, but also the only way for teachers to learn all their life and improve themselves.

\section{Colleges and Universities should Strengthen the Construction of Teachers in the Course of Ideological and Political Theory}

The information-based teaching ability of ideological and political theory teachers in colleges and universities can not keep up with the development of the times, and it has important relations with the phenomenon that colleges and universities do not attach importance to the teaching of ideological and political theory and the teachers of ideological and political theory have their own affairs. Especially with the rapid development of modern information technology, the complexity of information technology in micro-class has brought severe challenges to the teaching of ideological and political theory. However, due to the limited personal learning and organizational energy, especially in many colleges and universities, ideological and political theory teachers have heavy teaching tasks or concurrent management posts, which requires ideological and political theory teachers in addition to their own to strengthen the ability of information-based teaching. In addition to learning and recharging, it is very important to increase the construction of teaching team, so as to effectively stimulate and promote the improvement and promotion of teachers' information-based teaching ability.

\section{CONCLUSION}

The microcourse has changed the classroom teaching form of the traditional ideological and political theory course, has brought the reform of the course teaching organization mode, the classroom has become the space for students to discuss, think, practice and discriminate under the guidance of the teacher. Micro-course has brought about the change of assessment method, and the assessment of ideological and political theory has changed from "paying attention to the final examination" to "paying attention to the learning process". The teachers of ideological and political courses in colleges and universities should improve their own level of information technology, stick to the social reality and students' actual teaching contents, and meet the needs of students' comprehensive ability development.

\section{ACKNOWLEDGEMENT}

This paper is one of the achievements of the Youth backbone teacher training Plan of Henan Province in 2017, "the Research on the production and Application of Microcourse of ideological and political Theory in Colleges and Universities". This paper is one of the achievements of the key project of the education reform of the Yellow River Water Conservancy Vocational and Technical College in $2018<$ "course ideological and political" specialty education system construction and practice.

\section{REFERENCES}

[1] Wang Xueli. A study on the Countermeasures of ideological and political classroom Teaching in Colleges and Universities in the Micro-Epoch On the Microcourse and its Application in the classroom Teaching of ideological and political course [J]. Wisdom 2017 (35): 49-50.

[2] Li Xiaole, Wang Zhigang. On the Enlightenment of Microcourse to the Teaching Reform of ideological and political Theory course in Colleges and Universities [J]. Reform and opening up! 2018 (01): 51-53. 
[3] Feng Zhi, Zheng Xiaodan. New definition of Microcourse: from Technology Development to effective Design: an interview with Professor Hu Xiaoyong of South China normal University and teacher Hu Tiesheng of Foshan Education Bureau [J]. Digital Education 2015 (4): 56-60.

[4] Hu Tiesheng, micro-class: a new trend in the development of regional educational information resources [J]. Audio-visual Education Research 2011 (10): 61-65. 